\title{
ACRL guidelines
}

\section{for distance learning library services}

\section{The final version, approved July 1998}

$\mathrm{E}^{a}$ d. note: The "Guidelines" were approved by the ACRL Board of Directors at the 1998 Midwinter Meeting and by the ALA Standards Committee at the 1998 Annual Conference.

Library resources and services in insti-tutions of higher education must meet the needs of all their faculty, students, and academic support staff, wherever these individuals are located, whether on a main campus, off campus, in distance education or extended campus programs, or in the absence of a campus at all; in courses taken for credit or non-credit; in continuing education programs; in courses attended in person or by means of electronic transmission; or any other means of distance education. The "Guidelines" delineate the elements necessary to achieving these ends. The "Guidelines" are intended to serve as a gateway to adherence to the ACRL Standards in the appropriate areas.

The audience for the "Guidelines" includes administrators at all levels of post-secondary education, librarians planning for and managing distance learning library services, other librarians and staff working with distance learning program staff, faculty, and sponsors of academic programs, as well as accrediting and licensure agencies.

The decision to revise the 1990 "Guidelines" was made initially by the DLS Guidelines Committee, then the official mandate came from the DLS Executive Board at its final 1996 Midwinter meeting. The 1990 "Guidelines" resulted from the first revision of the original 1981 "Guidelines." As in that initial revision, the current decision to revise was based on the following identical, though increasingly critical, factors: nontraditional study becoming a more commonplace element in higher education; an increase in diversity of educational opportunities; an increase in the number of unique environments where educational opportunities are offered; an increased recognition of the need for library resources and services at locations other than main campuses; an increased concern and demand for equitable services for all students in higher education, no matter where the "classroom" may be; a greater demand for library resources and services by faculty and staff at distance learning sites; and an increase in technological innovations in the transmittal of information and the delivery of courses. To these may be added the decrease in central campus enrollments, the search for more cost-effective sources for post-secondary education, and the appearance and rapid development of the virtual or all-electronic university, having no physical campus of its own.

\section{Definitions}

"Distance learning library services" refers to those library services in support of college, university, or other post-secondary courses and programs offered away from a main campus, or in the absence of a traditional campus, and regardless of where credit is given. These courses may be taught in traditional or non-traditional formats or media, may or may not require physical facilities, and may or may not involve live interaction of teachers and students. The phrase is inclusive of courses in all post-secondary programs designated as: extension, extended, offcampus, extended campus, distance, distributed, open, flexible, franchising, virtual, synchronous, or asynchronous.

"Distance learning community" covers all those individuals and agencies, or institutions,

\section{About the author}

Prepared by the ACRL Distance Learning Section Guidelines Committeechaired by Harvey Gover, assistant campus librarian atWashingtonStateUniversity, Tri-Cities, e-mail:hgover@tricity.wsu.edu 


\section{Revising the "Guidelines"}

This revision of the 1990 ACRL "Guidelines" for Extended Campus Library Services was prepared by Harvey Gover, chair of the Guidelines Committee of the ACRL Distance Learning Section (DLS), formerly the Extended Campus Library Services Section. The revision is based upon input from members of the Guidelines Committee, members of the DLS Executive Board, the general membership of DLS, and other librarians and administrators involved in post-secondary distance learning programs from across the nation and around the world.

Major portions of the input for revision came from two open hearings: the first held on February 17, 1997, at the Midwinter Conference of the ALA in Washington, D.C. and the second on June 28 , 1997, at the ALA Annual Conference in San Francisco, California.

In response to requests for revision suggestions-which appeared in widely read national academic and library publications, distance education listservs, through the DLS Web site, and print publications-numerous other individuals, consortia, and representatives of professional and accrediting associations provided information on their own efforts to ensure excellence of library services for post-secondary distance learning programs.

Among the groups responding were: the Canadian Association of College and University Libraries of the Canadian Library Association; College Librarians and Media Specialists (CLAMS); the Commission on Colleges of the Northwest Association of Schools and Colleges (NASC); The Consortium for Educational Technology for University Systems (CETUS); the Interinstitutional Library Council (ILC) of the Oregon State System of Higher Education (OSSHE); Libraries and the Western Governors University Conference; the Southern Association of Colleges and Schools (SACS); and the Western Cooperative for Educational Telecommunications of the Western Interstate Commission for Higher Education (WICHE).

\section{Guidelines Committee members}

Members of the Guidelines Committee who initiated or contributed to the revision process include: Stella Bentley, University of California at Santa Barbara; Jean Caspers, Oregon State University; Jacqueline A. Henning, Embry-Riddle Aeronautical University; Sharon Hybki-Kerr, University of Arkansas, Little Rock: Gordon Lynn Hufford, Indiana University East; Ruth M. Jackson, West Virginia University; Chui-Chun Lee, SUNY-New Paltz; G.
Tom Mendina, University of Memphis; Virginia S. O'Herron, Old Dominion University; Mae O'Neal, Western Michigan University; Bill Parton, Arkansas Tech University; Mercedes L. Rowe, Mercy College; Dorothy Tolliver, Maui Community College Library; and Steven D. Zink, University of Nevada, Reno.

Others outside the Committee who contributed significantly to the cycle of revision include: Thomas Abbott, University of Maine at Augusta; Janice Bain-Kerr, Troy State University; Nancy Burich, University of Kansas, Regents Center Library; Anne Marie Casey, Central Michigan University; Tony Cavanaugh, Deakin University, Victoria, Australia; Monica Hines Craig, Central Michigan University; Mary Ellen Davis, ACRL; Tom DeLoughry, Chronicle Of Higher Education; Jill Fatzer, University of New Orleans, ACRL Board, Task Force on Outcomes; Jack Fritts, Southeastern Wisconsin Information Technology Exchange Consortium (SWITCH); Barbara GelmanDanley of SUNY Monroe Community College, Educational Technology, and the Consortium for Educational Technology for University Systems; Kay Harvey, Penn State, McKeesport; Maryhelen Jones, Central Michigan University; Marie Kascus, Central Connecticut State University; Barbara Krauth, Student Services Project Coordinator for the Western Cooperative for Educational Telecommunication of the Western Interstate Commission for Higher Education (WICHE); Eleanor Kulleseid, Mercy College; Rob Morrison, Utah State University; Kathleen O'Connor, Gonzaga University; Alexander (Sandy) Slade, University of Victoria, British Columbia, Canada; Mem Catania Stahley, University of Central Florida, Brevard Campus; Peg Walther, City University, Renton, Washington; Virginia Witucke, Central Michigan University; Jennifer Wu, North Seattle Community College and College Librarians and Media Specialists (CLAMS).

Special recognition is due Virginia S. (Ginny) OHerron who served throughout this cycle of revision as both a member of the Guidelines Committee and as Chair of the ACRL Standards and Accreditation Committee (SAC). In this dual role OHerron was instrumental in securing the placement of the Guidelines draft on the agendas not only of SAC, but also of the ACRL Board and the ALA Committee on Standards. In addition to her considerable contribution to the revision process as a member of the Guidelines Committee, O'Herron was then the primary facilitator of the final approval process.-Harvey Gover 
directly involved with academic programs or extension services offered away from a traditional academic campus, or in the absence of a traditional academic campus, including students. faculty, researchers, administrators, sponsors. and staff, or any of these whose academic work otherwise takes them away from on-campus library services.

"Originating institution" refers to the entity, singular or collective, its/their chief administrative officers and governance organizations responsible for the offering or marketing and supporting of distance learning courses and programs: the credit-granting body. Each institution in a multi-institutional cluster is responsible for meeting the library needs of its own students, faculty, and staff at the collective site.

"Library" denotes the library operation directly associated with the originating institution.

"Librarian-administrator" designates a librarian, holding a master's degree from an ALAaccredited library school, who specializes in distance learning library services, and who is directly responsible for the administration and supervision of those services.

\section{Philosophy}

The "Guidelines" assume the following precepts:

- Access to adequate library services and resources is essential for the attainment of superior academic skills in post-secondary education, regardless of where students, faculty, and programs are located. Members of the distance learning community are entitled to library services and resources equivalent to those provided for students and faculty in traditional campus settings.

- The instilling of lifelong learning skills through information literacy instruction in academic libraries is a primary outcome of higher education. Such preparation is of equal necessity for the distance learning community as it is for those on the traditional campus.

- Traditional on-campus library services themselves cannot be stretched to meet the library needs of distance learning students and faculty who face distinct and different challenges involving library access and information delivery. Special funding arrangements, proactive planning, and promotion are necessary to deliver equivalent library services and to maintain quality in distance learning programs. Because students and faculty in distance learning programs frequently do not have direct access to a full range of library services and materials, eq- uitable distance learning library services are more personalized than might be expected on campus.

- The originating institution is responsible, through its chief administrative officers and governance organizations, for funding and appropriately meeting the information needs of its distance learning programs in support of their teaching, learning, and research. This support should provide ready and equivalent library service and learning resources to all its students, regardless of location. This support should be funded separately rather than drawn from the regular funding of the library. In growing and developing institutions, funding should expand as programs and enrollments grow.

- The originating institution recognizes the need for service, management, and technical linkages between the library and other complementary resource bases such as computing facilities, instructional media, and telecommunication centers,

- The originating institution is responsible for assuring that its distance learning library programs meet or exceed national and regional accreditation standards and professional association standards and guidelines.

- The originating institution is responsible for involving the library administration and other personnel in the detailed analysis of planning. developing, and adding or changing of the distance learning program from the earliest stages onward.

- The library has primary responsibility for identifying, developing, coordinating, and providing resources and services, which meet both the standard and the unique information needs of the distance learning community. The librarian-administrator, either centrally located or at an appropriate site, should be responsible for ensuring that all requirements are met.

- Effective and appropriate services for distance learning communities may differ from, but must be equivalent to, those services offered on a traditional campus. The requirements of academic programs should guide the library's responses to defined needs. Innovative approaches to the design of special procedures or systems to meet these needs is encouraged.

- When resources and services of unaffiliated local libraries are to be used to support information needs of the distance learning community, the originating institution is responsible, through the library, for the development and periodic review of formal, documented, written agreements with those local libraries. Such re- 
sources and services are not to be used simply as substitutes for supplying adequate materials and services by the originating institution.

- The distance learning library program shall have goals and obj tives that support the provision of resources ! nd services consistent with the broader instituti nal mission.

\section{Management}

The chief administrative officers and governance organizations of the originating institution bear the fiscal and administrative responsibilities, through the active leadership of the library administration, to fund, staff, and supervise library services and resources in support of distance learning programs. As the principal and direct agent of implementation, the librarian-administrator should, minimally:

1. assess and articulate, on an ongoing basis, both the electronic and traditional library resource needs of the distance learning community, the services provided them, including instruction, and the facilities utilized;

2. prepare a written profile of the distance learning community's information needs;

3. develop a written statement of immediate and long-range goals and objectives for distance learning, which addresses the needs and outlines the methods by which progress can be measured;

4. promote the incorporation of the distance learning goals and objectives into those of the library and of the originating institution as a whole;

5. involve distance learning community representatives, including administrators, faculty, and students, in the formation of the objectives and the regular evaluation of their achievement;

6. assess, using the written profile of needs, the existing library support for distance learning, its availability, and appropriateness;

7. prepare and/or revise collection development and acquisitions policies to reflect the profile of needs;

8. participate with administrators, library subject specialists, and teaching faculty in the curriculum development process and in course planning for distance learning to ensure that appropriate library resources and services are available;

9. promote library support services to the distance learning community;

10. survey regularly distance learning library users to monitor and assess both the appropriateness of their use of services and resources and the degree to which needs are being met;

11. initiate dialog leading to cooperative agreements and possible resource sharing and/ or compensation for unaffiliated libraries;

12. develop methodologies for the provision of library materials and services from the library and/or from branch campus libraries or learning centers to the distance learning community;

13. develop partnerships with computing services departments to provide the necessary automation support for the distance learning community; and

14. pursue, implement, and maintain all the preceding in the provision of a facilitating environment in support of teaching and learning.

Additional areas of management responsibility are covered in sections on finances, personnel, facilities, resources, and services.

\section{Finances}

The originating institution should provide continuing, optimum financial support for addressing the library needs of the distance learning community sufficient to meet the specifications given in other sections of these "Guidelines," and in accordance with the appropriate ACRL Standards and with available professional, state, or regional accrediting agency specifications. This financing should be:

1. related to the formally defined needs and demands of the distance learning program;

2. allocated on a schedule matching the originating institution's budgeting cycle;

3. designated and specifically identified within the originating institution's budget and expenditure reporting statements;

4. accommodated to arrangements involving external agencies, including both unaffiliated and affiliated, but independently supported, libraries;

5. sufficient to cover the type and number of services provided the distance learning community; and

6. sufficient to support innovative approaches to meeting needs.

\section{Personnel}

Personnel involved in the management and coordination of distance learning library services include the chief administrators and governance organizations of the originating institution and the library administration and other personnel as appropriate, the librarian-coordinator managing the services, the library subject special- 
ists, additional professional staff in the institution, support staff from a variety of departments, and the administrator(s), librarian(s), and staff from the distance learning site(s).

The originating institution should provide, either through the library or directly to separately administered units, professional and support personnel with clearly defined responsibilities at the appropriate location(s) and in the number and quality necessary to attain the goals and objectives for library services to the distance learning program including:

1. a librarian-administrator to plan, implement, coordinate, and evaluate library resources and services addressing the information needs of the distance learning community;

2. additional professional and/or support personnel on site with the capacity and skills to identify informational needs of distance learning library users and respond to them directly;

3. classification, status, and salary scales for distance learning library personnel that are equivalent to those provided for other comparable library employees while reflecting the compensation levels and cost of living for those residing at distance learning sites; and

4. opportunities for continuing growth and development for distance learning library personnel, including continuing education, professional education, and participation in professional and staff organizations.

\section{Facilities}

The originating institution should provide facilities, equipment, and communication links sufficient in size, number, scope, accessibility, and timeliness to reach all students and to attain the objectives of the distance learning programs. Arrangements may vary and should be appropriate to programs offered. Examples of suitable arrangements include but are not limited to:

1. access to facilities through agreements with a non-affiliated library;

2. designated space for consultations, ready reference collections, reserve collections, electronic transmission of information, computerized data base searching and interlibrary loan services, and offices for the library distance learning personnel;

3. a branch or satellite library; and

4. virtual services, such as Web pages, Internet searching, using technology for electronic connectivity.

\section{Resources}

The originating institution is responsible for providing or securing convenient, direct physical and electronic access to library materials for distance learning programs equivalent to those provided in traditional settings and in sufficient quality, depth, number, scope, currentness, and formats to:

1. meet the students' needs in fulfilling course assignments (e.g., required and supplemental readings and research papers) and enrich the academic programs;

2. meet teaching and research needs; and

3. accommodate other informational needs of the distance learning community as appropriate.

When more than one institution is involved in the provision of a distance learning program, each is responsible for the provision of library materials to students in its own courses, unless an equitable agreement for otherwise providing these materials has been made. Costs, services, and methods for the provision of materials for all courses in the program should be uniform.

Programs granting associate degrees should provide access to collections which meet the "Association of College and Research Libraries (ACRL) Guidelines for Two-Year College Learning Resources Programs" and the "Statement on Quantitative Standards." Programs granting baccalaureate or master's degrees should provide access to collections that meet the standards defined by the "ACRL Standards for College Libraries." Programs offering doctorate degrees should provide access to collections that meet the standards defined by the "ACRL Standards for University Libraries."

\section{Services}

The library services offered to the distance learning community should be designed to meet effectively a wide range of informational, bibliographic, and user needs. The exact combination of central and site staffing for distance learning library services will differ from institution to institution. The following, though not necessarily exhaustive, are essential:

1. reference assistance;

2. computer-based bibliographic and informational services;

3. reliable, rapid, secure access to institutional and other networks including the Internet;

4. consultation services;

5. a program of library user instruction de- 
signed to instill independent and effective information literacy skills while specifically meeting the learner-support needs of the distance learning community:

6. assistance with nonprint media and equipment;

7. reciprocal or contractual borrowing, or interlibrary loan services using broadest application of fair use of copyrighted materials:

8. prompt document delivery such as a courier system and/or electronic transmission;

9. access to reserve materials in accordance with copyright fair use policies;

10. adequate service hours for optimum access by users; and

11. promotion of library services to the distance learning community, including documented and updated policies, regulations and procedures for systematic development, and management of information resources.

\section{Documentation}

To provide records indicating the degree to which the originating institution is meeting these "Guidelines" in providing library services to its distance learning programs, the library, and when appropriate, the distance learning library units, should have available current copies of at least the following:
1. printed user guides:

2. statements of mission and purpose, policies, regulations, and procedures;

3. statistics on library use;

4. statistics on collections:

5. facilities assessment measures:

6. collections assessment measures;

7. data on staff and work assignments;

8 . institutional and internal organization charts;

9. comprehensive budget(s):

10. professional personnel vitae;

11. position descriptions for all personnel;

12. formal, written agreements;

13. automation statistics;

14. guides to computing services;

15. library evaluation studies or documents;

16. library and other instructional materials and schedules; and

17. evidence of involvement in curriculum development and planning.

\section{Library education}

To enable the initiation of an academic professional specialization in distance learning library services, schools of library and information science should include in their curriculum courses and course units this growing area of specialization within librarianship.

\section{Academic/Research Librarian of the Year Award}

\section{The 1999 winner is . . .}

- a leader in the profession

- respected for research

- an innovator who shares ideas

- a developer of library programs

\section{and is still out there.}

ACRL needs your nominations for the 1999 Academic/Research

Librarian of the Year. Information on award criteria and the nomination procedures are available at http://www.ala.org/acrl/aryl.html or from Jack Briody in the ACRL office, phone (800) 545-2433, ext. 2516 or e-mail jbriody@ala.org.

Submission Deadline: December 1, 1998 